\title{
Inhibition of myostatin signaling increases glucose in insulin-deficient diabetic mice
}

\author{
Qian Wang ${ }^{*}$, Tingqing Guo, Alexandra C McPherron \\ From Metabolism, diet and disease \\ Washington, DC, USA. 29-31 May 2012
}

\section{Background}

Myostatin (MSTN), a TGF- $\beta$ superfamily member, is a negative regulator of muscle mass that plays an important role in metabolism. Mstn $\mathrm{KO}$ mice have increased muscle mass, reduced adipose mass and improved insulin sensitivity. We have recently shown that MSTN inhibition in muscle prevents the development of diabetes in a mouse model of lipodystrophy. Whether inhibition of MSTN in a type I diabetes model would improve hyperglycemia is unknown.

\section{Materials and methods}

We used streptozotocin (STZ)-treated C57 mice in which the insulin-producing $\beta$-cells were specifically damaged leading to hyperglycemia. After overt diabetes developed, the STZ-treated mice were injected with a MSTN inhibitor, a soluble Activin receptor type II B (ACVR2B:Fc). Blood glucose levels were measured regularly by glucometer. Pyruvate tolerance and glutamine tolerance tests were performed and several hormones in the serum were measured. Real-time PCR was used to compare the expression level of some genes involved in gluconeogenesis.

\section{Results}

The soluble ACVR2B:Fc-treated STZ mice have higher blood glucose levels compared with untreated STZ mice. There were no differences in insulin and glucagon levels between ACVR2B:Fc treated or untreated STZ mice. However, there were higher levels of the glucocorticoid corticosterone in soluble ACVR2B:Fc-treated mice. Realtime PCR data showed that the expression of the PEPCK gene was increased significantly in ACVR2B:Fc-treated mice.

\section{Conclusion}

Our data suggest that the soluble ACVR2B:Fc treatment worsens hyperglycemia possibly due to increased gluconeogenesis. These data suggest that MSTN inhibition will not be useful for treating type I diabetes.

Published: 1 June 2012

doi:10.1186/1753-6561-6-S3-P52

Cite this article as: Wang et al:: Inhibition of myostatin signaling 2012 6(Suppl 3):P52.

Submit your next manuscript to BioMed Central and take full advantage of:

- Convenient online submission

- Thorough peer review

- No space constraints or color figure charges

- Immediate publication on acceptance

- Inclusion in PubMed, CAS, Scopus and Google Scholar

- Research which is freely available for redistribution 